\title{
STRATEGI PENGEMBANGAN DAN IMPLEMENTASI SMART CITY PEMERINTAH KOTA PONTIANAK
}

\author{
Karina Oktriastra \\ Politeknik STIA LAN Bandung, Indonesia \\ Email: oktriastrakarina@gmail.com
}

\begin{tabular}{lr}
\hline \multicolumn{2}{c}{ Artikel info } \\
\hline \multicolumn{2}{c}{ Artikel history } \\
Diterima $\quad: 29-11-2020$ \\
Direvisi $\quad: 06-12-2020$ \\
Disetujui $\quad: 17-12-2020$
\end{tabular}

Kata kunci: Implementasi, Pengembangan, Kolaborasi, Smart City

Keywords: Implementation, Development, Collaboration, Smart City

\begin{abstract}
Abstrak
Tujuan penelitian ini membahas tentang implementasi smart city di kota Pontianak yang masih mengalami kekurangan integrasi aplikasi, sumber daya peralatan yang belum terpetakan, infrastruktur pendukung yang kurang, sosialisasi masyarakat yang kurang, kurangnya kerjasama dan kolaborasi dengan pihak lain, serta kurangnya keamanan sistem informasi. Pembatasan rencana. Metode penelitian yang digunakan adalah metode pengumpulan data kualitatif melalui triangulasi. Kemudian menganalisis data yang dikumpulkan sesuai dengan teori Lev-On dan melalui matriks SWOT, menganalisis penerapan faktor penghambat dan pendukung, serta kelebihan, kekurangan, peluang dan ancaman, serta merumuskan strategi. Hasil penelitian menunjukkan bahwa implementasi dan pengembangan smart city Pemerintah Kota Pontianak telah berjalan, dan dapat dikembangkan melalui strategi aktif, yaitu memanfaatkan kekuatan untuk menangkap peluang melalui integrasi aplikasi, dan mengalokasikan sumber daya perangkat melalui pencarian bakat dan talent pool. , Mengalokasikan anggaran di setiap OPD, melakukan pendidikan dan publisitas bekerja sama dengan sektor swasta, akademisi, media massa, komunitas dan publik, menggunakan bakat lokal, menggunakan rencana kota pintar untuk penelitian dan pengembangan, dan kemudian menyusun data yang relevan dan manajemen keamanan jaringan Sistem regulasi. Untuk mengimplementasikan prosedur tersebut, pemerintah Kota Pontianak dapat menggunakan aplikasi JEPIN (Pontianak Integration Window) untuk bekerjasama dengan pihak swasta, akademisi, media massa, komunitas dan komunitas serta merancang prosedur operasi standar (SOP) terkait keamanan untuk mengintegrasikan aplikasi Dan interoperabilitas. Data dan jaringan melindungi pengoperasian rencana kota pintar sehingga dapat berjalan dengan lancar dan melalui langkah- langkah yang benar.
\end{abstract}

\footnotetext{
Abstract

This thesis discusses the implementation of smart city in Pontianak which is still constrained by the lack of application integration, unmapped civil servants resources, lack of supporting infrastructure, lack of socialization to the community, lack of cooperation and collaboration with other parties, and the absence of an information system security plan. The research method used is a qualitative approach with data collection through triangulation.. The data then analyzed based on the Lev-On theory and through the SWOT matrix, analyzing inhibiting and supporting factors as well as the suitability of strengths, weaknesses, opportunities and threats to then formulate strategies. The results of the research are the implementation and development of smart cities in the Pontianak City Government that have been running and can be developed through an aggressive strategy, namely utilizing the power to seize opportunities through application integration, mapping civil servants resources through talent scouting and talent pools, allocating budgets in each organization, conducting collaboration with the private sector, academia, mass media, communities and the public for education and outreach, utilization of local talent, using research and development for smart city programs then drafting regulations regarding data and network security management systems. To carry out these programs, the Pontianak City Government can integrate applications and interoperability by utilizing JEPIN (Jendela Pontianak Terintegrasi) application, collaborating with the private sector, academia, mass media,
} 
$\overline{\text { communities and public then designing standard operating procedures }}$ (SOPs) regarding security data and network to protect the operational process of the smart city program so that it can run smoothly and through the right steps.

Koresponden author: karina oktriastra Email: oktriastrakarina@gmail.com artikel dengan akses terbuka dibawah lisensi CC BY SA

2020

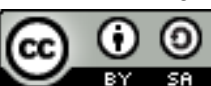

\section{Pendahuluan}

Di era globalisasi, dengan perkembangan teknologi yang semakin kompleks, kita telah memasuki Revolusi Industri 4.0 yang berfokus pada ekonomi digital, kecerdasan buatan, big data, robotika, dan dikenal juga sebagai disruptive innovation. Inovasi yang mengganggu adalah inovasi yang dapat membantu menciptakan pasar baru, mengganggu atau mengganggu pasar yang ada, dan pada akhirnya menggantikan teknologi sebelumnya tersebut. Dalam inovasi yang mengganggu ini, produk atau layanan biasanya dikembangkan dengan cara yang tidak diharapkan pasar dengan menciptakan berbagai jenis konsumen di pasar baru dan menurunkan harga di pasar pertama (Bower \& Christensen, 1995). Dalam menciptakan inovasi tersebut (seperti terlihat pada indikator Indeks Daya Saing Global World Economic Forum 2017-2018), Indonesia menempati urutan ke-36 dari 137 negara. Oleh karena itu, diperlukan inovasi Indonesia untuk mengatasi keterbatasan kapabilitas, sumber daya, dan jaringan yang dapat didukung dengan bekerja sama dengan pemerintah, swasta, akademisi, 
komunitas, dan masyarakat. Hal ini juga sesuai dengan konsep Revolusi Industri Keempat. Tujuan Revolusi Industri Keempat adalah untuk terus menerus (real-time) memberikan layanan cerdas untuk meminimalkan penggunaan sumber daya dan memaksimalkan penggunaan infrastruktur yang ada (Lom et al., 2016). Dengan tantangan-tantangan tersebut, diharapkan pemerintah daerah dapat mengambil langkah-langkah strategis sesuai dengan kemampuan dan kapabilitas yang diperlukan pihak berwenang untuk menangani permasalahan publik yang muncul.

Namun, seperti setiap wilayah dan organisasi, masih ada kesenjangan antara harapan dan kenyataan dalam hal pencapaian tujuan yang diharapkan. Beberapa permasalahan dan kekurangan yang ditemukan dalam pengembangan smart city di Pontianak: (1) Pada Organisasi Perangkat Daerah (OPD) di lingkungan Pemerintah Kota Pontianak, pengembangan aplikasi dan pengelolaan data masih belum terintegrasi dan optimal. Dari 79 sistem informasi berbasis TIK yang ada di 17 OPD Pontianak, baru ada 9 aplikasi yang terintegrasi yaitu yang terkoneksi dengan website Pontianak Smart City yang diakses pada Senin, 17 Juni 2019. , Dan kemudian ada beberapa tautan yang tidak dapat diakses, seperti CCTV mengalir. Dalam waktu yang bersamaan, website tersebut juga terhubung dengan website utama Pemerintah Kota Pontianak yaitu www.pontianakkota.go.id. (2) Kapasitas sumber daya perangkat belum dipetakan dalam pengembangan, pengelolaan, dan pemanfaatan teknologi, informasi, dan komunikasi yang mendukung Program Kota Cerdas. Kemampuan sumber daya perangkat tersebut nantinya akan dilihat melalui nilai Indeks SPBE berdasarkan indeks Electronic Government System Evaluation (SPBE) dan pengoperasian layanan dalam Smart City Plan. (3) Prasarana pendukung Kota Pintar Pontianak belum terbentuk. Sedangkan untuk Pontianak (Tim Teknis Pontianak Smart City, 2019a): Pontianak, CCTV dan sensor di beberapa lampu lalu lintas di Pontianak. Ruang server Pontianak, ruang big data Pontianak, ruang inkubator start up Pontianak, data center Pontianak dan media center belum dibangun. Untuk saat ini ketersediaan jaringan sudah setinggi jaringan 4G / 3G, dan jaringan astinet dan indihome digunakan untuk akses broadband antar jaringan OPD. Setiap jaringan OPD sudah memiliki jaringan Internetnya masing-masing. Selain itu, Internet gratis disediakan di 20 taman. Internet. Kota Pontianak. (4) Masyarakat Pontianak masih kekurangan pelayanan sosial untuk pelayanan publik online, sehingga masih ada sebagian masyarakat yang belum memahami pelayanan online, juga masih belum menggunakan dan menggunakan aplikasi yang sudah ada. Belum ada grafik jumlah masyarakat yang dapat mengakses layanan publik online yang disediakan oleh Kota Pontianak dari 627.021 penduduk Kota Pontianak (Badan Statistik Kota Puntanaque, 2018) (5) Pemerintah daerah dan masyarakat Meksiko Tidak ada kerja sama terbaik antara Pontianak. Misalnya saat mengembangkan aplikasi smart city, masyarakat tidak berpartisipasi aktif dalam pembuatan aplikasi yang sudah ada. Misalnya komunitas yang bergerak di bidang lingkungan yaitu komunitas Gerakan Sungai Kapuyas (GSK), Komunitas Sungai Puda (KSP), bidang pendidikan yaitu komunitas Aku Belajar, Ikatan 1000 Guru Kalimantan dan komunitas lainnya di Pontianak. (6) Rencana keamanan sistem informasi belum dirancang untuk mencegah ancaman terhadap sistem dan mendeteksi serta memperbaiki dampak kerusakan sistem. Oleh karena itu, pertanyaan pokok yang diangkat dari penelitian ini adalah "Bagaimana strategi pengembangan dan implementasi Pemerintah Kota Pintar Pontianak?" 
Penelitian sebelumnya yang dijadikan acuan adalah kota pintar Eropa (Caragliu et al., 2009). Penelitian menggunakan metode kuantitatif. Hasil penelitian menunjukkan bahwa jika investasi sumber daya dan modal sosial serta infrastruktur sistem komunikasi tradisional dan modern dapat mendorong pertumbuhan ekonomi, Kemudian kota menjadi bijak dalam mengelola sumber daya alam secara bijak melalui tata kelola partisipatif, mewujudkan pembangunan berkelanjutan dan kualitas hidup, serta mampu memberikan pelayanan yang baik kepada masyarakat. Perbedaan dalam penelitian tersebut adalah pada penelitian ini, penulis akan membahas bagaimana Pemerintah Kota Pontianak dapat mengembangkan strategi smart city melalui kerjasama dengan pihak swasta, akademisi, media massa, dan masyarakat. Kemudian ada majalah "Bandung City Smart City Implementation" (Mursalim, 2017). Hasil penelitian menunjukkan bahwa implementasi kebijakan smart city Kota Bandung belum tersosialisasi dan dikomunikasikan dengan baik, terutama komunikasi yang buruk dengan SKPD atau instansi terkait. Akibatnya, banyak masyarakat di Bandung yang belum memahami smart city. Unsur penting untuk mendukung kota pintar Bandung adalah smart people, smart government, yang bersumber dari sumber daya yaitu ketersediaan teknologi dan perangkat pendukung.Dari aspek penyebaran harus didukung oleh pelaksana dan harus didukung dari perspektif birokrasi, Demi terciptanya pemerintahan yang cerdas dan bijaksana. Orang-orang di kota pintar bisa sukses. Perbedaan antara penelitian ini adalah bahwa penelitian ini akan membahas implementasi pengembangan smart city dari perspektif visi, baseline development, pemilihan target dan indikator, pengembangan lembaga efisiensi tinggi, pilot project, dan investasi teknologi, bukan hanya dari perspektif smart city. Mulailah dengan elemen pendukung. Kemudian dalam tesis, metode deskriptif digunakan untuk "mewujudkan kota yang responsif melalui kota pintar" (Insani, 2017) untuk mempelajari konsep kota pintar yang menggunakan teknologi informasi dan berfokus pada kota digital. Konsep yang lebih luas untuk memfasilitasi masyarakat karena mencakup 6 dimensi (Greco \& Bencardino, 2014) yaitu smart government, smart economy, smart people, smart travel, smart environment dan smart life. Dalam penelitian ini, penulis tidak hanya membahas enam aspek, tetapi juga membahas strategi yang diterapkan dengan pendekatan quadruple spiral yaitu pemerintah, swasta, universitas, komunitas, komunitas dan media massa.

Hal ini diyakini bahwa penelitian ini perlu dilakukan. Tujuannya adalah untuk memotret dan menganalisis implementasi kota pintar di Kota Pontianak sejak berdiri hingga saat ini, serta menganalisis faktor-faktor penahan dan pendukungnya melalui analisis matriks SWOT yaitu keunggulan, kelemahan, peluang dan tantangan. Dan merumuskan strategi pengembangan dan implementasi pemerintahan kota pintar. Kota Pontianak dapat meningkatkan kapasitas sumber daya perangkat dan meningkatkan keamanan sistem informasi yang baik melalui kerjasama antara swasta, akademisi, komunitas, media massa, dan masyarakat, sehingga mencapai derajat integrasi yang lebih tinggi. Diharapkan dengan adanya penelitian ini dapat bermanfaat untuk pengembangan teori konsep Kota Cerdas Pontianak dan kontribusi ideologis dalam bidang pengelolaan pembangunan nasional, khususnya kebijakan pembangunan daerah. 


\section{Metode Penelitian}

Untuk melakukan penelitian secara kualitatif dengan melakukan penelitian masalah yang lebih abstrak, tujuannya adalah untuk melakukan penelitian kualitatif melalui observasi, wawancara dan pengalaman langsung, sehingga memperoleh wawasan tentang gejala, fakta atau kenyataan. Menurut metode Creswell (Raco, 2010), partisipan atau partisipan penelitian diwawancarai dengan menanyakan kepada partisipan umum atau pertanyaan yang cukup luas berupa kata atau teks untuk menggali dan memahami gejala sentralnya, kemudian dilanjutkan dalam bentuk deskripsi atau deskripsi. Analisis untuk menjelaskan atau menjelaskan gejala. Secara pribadi merefleksikan dan menguraikan penelitian sebelumnya. Hasil akhir penelitian juga dipengaruhi oleh pendapat, ide dan pengetahuan peneliti. Penyedia informasi yang diwawancarai dalam penelitian ini adalah (Tim Teknis Pontianak Smart City, 2019b), organisasi dengan aplikasi yang tidak terintegrasi dengan website smart city, private group / programmer, akademisi, komunitas, komunitas, dan media massa.

Lokasi penelitian berada di Kota Pontianak, khususnya Dinas Pimpinan Kota Cerdas Pontianak yaitu Dinas Komunikasi dan Informatika Kota Pontianak dan stakeholders terkait. Pekerjaan penelitian dilakukan oleh peneliti yang berperan sebagai alat atau alat penelitian, mereka akan mengumpulkan ide, peserta akan mengkomunikasikan ide tersebut melalui wawancara, kemudian mengembangkan ide atau ide baru (Raco, 2010).

Dalam kegiatan pengumpulan data, analisis data dilakukan dengan melakukan reduksi data yaitu proses penyaringan, pemfokusan, pengabstrakan dan transformasi data kasar dari awal hingga akhir penelitian. Data yang dikumpulkan dan direduksi diharapkan sesuai dan relevan untuk mendukung informasi yang diperoleh agar dapat menarik kesimpulan dan menjawab tujuan penelitian. Analisis data melalui triangulasi (yaitu observasi) dalam bentuk observasi eksternal biasanya mengamati bagaimana kebijakan smart city diimplementasikan dalam organisasi perangkat daerah, bagaimana respon masyarakat terhadap aplikasi ini, dan beberapa layanan sistem online, seperti GENCIL (Government Smart City) dan Landmark), JEPIN (Integrated Pontianak Window) dan website Pontianak Smart City, Wawancara, yaitu komunikasi langsung atau virtual (melalui WhatsApp) untuk mencari informasi terkait strategi perumusan kebijakan, serta mengimplementasikan inovasi dan kegiatan saat mengimplementasikan strategi tersebut. Kemudian melakukan penelitian dokumen yaitu mengkaji seluruh dokumen yang terkait dengan strategi pengembangan kebijakan Kota Pintar Pontianak dan dokumen teknis operasional.

\section{Hasil dan Pembahasan}

Kota Pontianak dengan jumlah penduduk 637.723 jiwa pada tahun 2018 (BPS Kota Pontianak, 2019) yang dapat digunakan telepon genggam (Hp) / wireless atau komputer (PC) / desktop, laptop / hingga 67,71\% laptop dan tablet Akses Internet termasuk media sosial. Kota Pontianak masih menghadapi beberapa tantangan yang perlu diselesaikan. (Tim Teknis Kota Cerdas Pontianak, 2019b) Tantangan tersebut antara lain: a) meningkatkan kualitas pelayanan dasar pemerintah, b) menangani permasalahan lingkungan dan bencana, khususnya bencana asap, c) pembangunan ekonomi dan daya saing daerah. Secara umum, perlu dicarikan solusi atas tantangan tersebut guna mewujudkan visi Kota Pontianak dalam meningkatkan sumber daya manusia (SDM) dan pelayanan publik terdepan sebagai kota ekuator yang berwawasan lingkungan. 
Untuk mengatasi permasalahan tersebut maka pembangunan daerah harus dilakukan secara bijak, yaitu kecepatan penyelesaian masalah lebih cepat dari pada kecepatan penyelesaian masalah itu sendiri. Solusi cerdas di sini adalah dengan menerapkan ekosistem kota pintar (smart city) yang memungkinkan pemerintah, swasta, akademisi, komunitas, media massa dan elemen sosial untuk berpartisipasi dalam pembangunan perkotaan. Oleh karena itu, diharapkan melalui konsep smart city semakin baik pengukuran wilayah melalui kinerja pengelolaan sumber daya, kinerja tersebut dapat lebih efektif, berkelanjutan dan melibatkan seluruh aspek masyarakat.

Visi dan misi pembangunan Kota Pintar Pontianak tidak terlepas dari visi dan misi pembangunan daerah yaitu RPJPD, RPJPM dan visi misi pembangunan nasional. Selain sesuai dengan pembangunan daerah dan nasional, visi dan misi tersebut juga harus dirumuskan dengan memperhatikan harapan berbagai kalangan yang hidup di Pontianak, agar pemanfaatan dan pengembangan teknologi dapat menyelesaikan segala sesuatu mulai dari masalah lingkungan kecil hingga masalah perkotaan yang lebih luas. masalah.

Dalam RPJP (Rencana Pembangunan Jangka Panjang) Pontianak yang tertuang dalam Peraturan Kota Pontianak Nomor 10 Tahun 2008 disebutkan bahwa visi pembangunan jangka panjang Pontianak adalah "Kota Pontinac mencapai garis katulistiwa yang sejahtera melalui perdagangan dan jasa yang ramah lingkungan". Ini memiliki visi Pontianak. Dijelaskan sebagai berikut:

a. Satu jenis. Kota Khatulistiwa merupakan ciri khas Kota Pontianak yang dilalui garis katulistiwa dan bukan milik kota-kota lain di Indonesia.

b. Kemakmuran artinya dalam 20 tahun ke depan masyarakat akan memiliki pendapatan yang cukup untuk memenuhi kebutuhan dasar: pangan, sandang, papan, air bersih, keamanan, pendidikan, kebersihan, pekerjaan, hak-hak dasar lainnya dan partisipasi dalam pengambilan keputusan, sehingga semua rencana jangka panjang, jangka menengah. (Lima tahun), rencana tahunan, rencana dan semua kegiatan pemerintah, swasta dan sektor publik ditujukan untuk menciptakan kesejahteraan masyarakat.

c. Pengertian lingkungan berarti bahwa berbagai pertimbangan arah pembangunan daerah, kebijakan, rencana, kegiatan, dan anggaran harus didasarkan pada pertimbangan kondisi daya dukung lingkungan, dan upaya peningkatan kualitas lingkungan.

d. Perdagangan dan jasa berarti kehidupan ekonomi masyarakat yang didominasi oleh sektor perdagangan, tersedianya sarana perdagangan, seperti perusahaan niaga, pusat perbelanjaan, supermarket dan bentuk pasar modern lainnya, tersedianya fasilitas pelayanan, seperti perkantoran, pameran, konferensi, Hiburan, olahraga, layanan pribadi, dan layanan komunitas.

Visi tersebut dijabarkan dalam enam tugas pembangunan, yaitu:

1. Menciptakan masyarakat yang bermutu tinggi, mulia, beradab budaya;

2. Mewujudkan masyarakat sipil, manusiawi, dengan masalah sosial yang lebih sedikit, hak-hak sipil yang lebih berdaya dan terjamin;

3. Mewujudkan pertumbuhan ekonomi dan investasi dalam kesejahteraan dan keadilan;

4. Mewujudkan kota perdagangan, jasa, koperasi, dan usaha kecil dan menengah untuk menyerap tenaga kerja dan memajukan kesejahteraan; 
5. Mewujudkan sarana perdagangan dan jasa yang berwawasan lingkungan, infrastruktur, tata ruang dan kawasan perkotaan;

6. Mewujudkan pemerintahan yang baik (good governance), yaitu masyarakat yang memahami politik dan taat hukum.

Pengembangan dan implementasi Pemerintahan Kota Pintar Pontianak Kota Cerdas Pontianak dimulai pada tahun 2015, diikuti dengan Gerakan 1.000 Kota Cerdas Indonesia, kemudian didirikan Layanan Komunikasi dan Informasi (Diskominfo) Pontianak pada tahun 2017, dan kemudian merumuskan wilayahnya. Rencana Pembangunan Jangka Menengah (kemudian dilanjutkan menyusun Rencana Induk 2015-2019, dan merumuskan Rencana Induk 2019, dari rencana induk dibagi rencana dan kegiatan, kemudian melalui Rencana Jangka Menengah Daerah (RPJMD) baru untuk evaluasi. Badan mendorong inovasi-inovasi yang dirancang oleh Organisasi Perangkat Daerah (OPD), kemudian didampingi oleh tim teknis, juga ada beberapa program pendampingan sistem di Organisasi Perangkat Daerah (OPD). Program-program ini akan dibantu oleh Diskominfo untuk pengembangan sistem selama tiga tahun. Lepaskan bantuan.

Interoperabilitas desain sistem telah direalisasikan dalam anggaran elektronik, seperti integrasi database pada sistem informasi manajemen keuangan dan akuntansi (SIMAKDA), dan pengembangan sistem informasi perencanaan (SIPP) menjadi gudang. Gudang menjadi situs web database terpadu.

Kemudian (Miriam \& Lev-On, 2013), lima hal yang dapat dilakukan dalam rangka membangun "smart city" adalah yang akan diterapkan di Pontianak dari tahun 2016 hingga 2019:

1. Ciptakan city vision dengan partisipasi publik Seperti yang diungkapkan Diskominfo Pontianak, buka forum dan terima pendapat dari Komunitas Rumah Aktif, Komunitas Rumah Aktif juga bersama-sama membentuk Aplikasi Jendela Terpadu Pontianak (JEPIN). Ini juga memungkinkan akronim untuk ditampilkan kepada publik. Visi Kota Pintar Pontianak adalah "Kota Pontinac Khatulistiwa, Cerdas, Kreatif, Inovatif dan Ramah Lingkungan”. Konsep kota pintar yang tertuang dalam Rencana Induk Kota Pintar (2019: 8) adalah ekosistem, pemerintahan, industri, dan cendekiawan. Partisipasi elemen sosial diukur dari kinerja pengelolaan sumber daya untuk menjadikan kota lebih baik, sehingga menjadikan kota lebih efisien dan berkelanjutan, serta melibatkan seluruh aspek masyarakat. Hal ini juga termasuk dalam misi keenam Walikota Pontianak 2019-2024 (RPJP 2019), yaitu "meningkatkan peran serta masyarakat untuk mewujudkan pembangunan yang bersih, hijau, aman, tertib, berwawasan lingkungan dan berkelanjutan. City " (Tim Teknis Pontianak Smart City, 2019c). Masyarakat juga berpartisipasi dalam pengambilan keputusan, seperti dalam kegiatan Musrenbang di tingkat desa dan kecamatan, untuk merumuskan rencana jangka panjang, jangka menengah (5 tahun), rencana tahunan, program, dan semua kegiatan pemerintah, swasta dan masyarakat, dengan harapan dapat melaksanakan semua kegiatan. Ciptakan kesejahteraan komunitas.

2. Menyusun benchmark, menetapkan target dan memilih indikator. Dari pemerintah Pontianak diharapkan master plan yang dirumuskan tahun 2019 dapat menjadi acuan evaluasi kegiatan sebelumnya sejak diluncurkannya smart city tahun 2016, sehingga mampu memperbaiki, meningkatkan kapasitas kelembagaan dan pemanfaatan Peluang untuk berkolaborasi dengan pihak lain yang dapat mengakselerasi dan meningkatkan 
sumber daya lokal Pontianak melalui pihak swasta, akademisi, media massa, komunitas dan masyarakat.

3. Terus berbenah, semoga Pemerintah Kota Pontianak dapat mengadopsi prinsip awal yaitu perampingan organisasi, sehingga dapat menetapkan tujuan yang terukur dan memilih indikator yang dapat mengukur kemajuan. Pemerintah Pontianak juga dapat mendeteksi keberhasilan tujuan yang telah diselesaikan. Desain bisa menjadi rencana aktivitas jangka panjang saat dimulai.

4. Berawal dari "pilot project" di aplikasi Pontianak, pengerjaannya dilakukan melalui aplikasi Gencil, yang telah diunduh 5.000 kali sejak diluncurkan pada Maret 2016 hingga Agustus 2018. Aplikasi tersebut Sedikitnya 82 laporan publik telah diterima, 77 di antaranya diproses (Tim Teknis Pontianak Smart City, 2019a). Gencil adalah aplikasi yang digunakan sebagai wadah pelaporan permasalahan yang terdapat di Kota Pontianak, dan instansi terkait akan menindaklanjutinya melalui fungsi Lava elektronik (laporan elektronik warga). Selain itu, aplikasi ini akan terus dikembangkan dengan aplikasi JEPIN (jendela Pontianak terintegrasi) yang merupakan kerjasama dengan komunitas programmer aktif keluarga yang aktif mengikuti kegiatan bakti sosial di tahun 2020. Saat aplikasi JEPIN yang dikunjungi pada 5 Juni 2020 ini memuat beberapa halaman yaitu halaman bertajuk Smart City. Ada beberapa fungsi disini, diantaranya peta sebaran Pontianak Covid-19, smart government, smart brand, dan smart environment. Ekonomi pintar, kehidupan cerdas, masyarakat pintar, agenda / event Pontianak, infografis, streaming CCTV, berita, laporan, harga komoditas dan panggilan penting. Dalam fungsi ini merupakan alamat website yang terkait dengan sistem pelayanan informasi dan informasi masing-masing organisasi perangkat daerah, dan menjadi direktori yang dapat dengan mudah mengakses semua layanan sistem informasi dari OPD Pontianak. Kemudian pada halaman selanjutnya terdapat informasi tujuan, akomodasi dan memasak, kemudian halaman aplikasi yang akan menautkan ke 5 aplikasi berbasis Android, yang dapat diunduh di Google Play atau website Waroeng Kite, yang untuk belanja online Website memudahkan masyarakat untuk menemukan produk UMKM Pontianak, SiPACAK (sistem pelaporan peristiwa penting bagi ketua RT), yang melaporkan semua kejadian yang berhubungan dengan kependudukan, seperti kelahiran, kematian, perkawinan, perceraian, dll, kemudian Pontianak Disaster SIPD (Warning System Application), Rumah Sakit Pontianak Online yaitu Rumah Sakit Sultan Syarif Muhammad Alkadrie Pontianak dan aplikasi antrian rawat jalan DPMTK Android, yang merupakan aplikasi resmi Biro Pelayanan Perizinan Terpadu Pontianak untuk memudahkan pelayanan pendaftaran izin, Pelacakan lisensi, periksa alokasi, periksa keaslian lisensi dan simulasikan tarif retribusi.

5. Menjadi investor dalam teknologi yang sedang dibangun. Upaya Pemerintah Kota Pontianak antara lain penyediaan ruang server di Diskominfo Pontianak sebagai salah satu infrastruktur teknis yang direncanakan untuk memfasilitasi seluruh aplikasi yang akan diintegrasikan melalui aplikasi jendela terpadu Pontianak (JEPIN). Kemudian juga menggandeng pihak-pihak seperti Telkom untuk menyediakan wifi gratis di 20 taman di Kota Pontianak, 20 CCTV dari Dinas Perhubungan, 6 Astinets, dan kemudian Pontianak Center (Pontian Interactive Center) Sebagai pusat komando untuk berbagai keperluan teknis di Pontianak. 
Analisis matriks SWOT adalah metode perencanaan strategis yang digunakan untuk mengevaluasi kekuatan, kelemahan, peluang dan ancaman proyek atau spekulasi bisnis.

Berdasarkan hasil wawancara dengan pemerintah, Dinas Komunikasi dan Informatika Pontianak, Dinas Aset Biro Keuangan Daerah Pontianak, redaksi dan voice reporter Kalbar, dan programmer PT GENCIL (Pemerintah Kota Pintar dan Bangunan). RIDI, Komunitas Mobile Home Kota Pontianak, Dosen Proyek Riset Informatika, Fakultas Teknik, Universitas Tanjung Pura, Kota Pontianak, dan Kota Pontianak memiliki tiga jabatan yaitu perdagangan, perhotelan dan jasa akomodasi, pengabdian masyarakat, sosial dan Individu dan Industri Konstruksi Secara garis besar kita belum mengetahui tentang rencana smart city Pontianak, namun kita sudah mengetahui tentang aplikasi berbasis Gencil Android yang dapat digunakan untuk melaporkan permasalahan yang terdapat di Pontianak.

Berdasarkan perhitungan tabel IFAS dan EFAS diperoleh skor hasil IFAS 2,65 dan skor hasil EFAS 2,81. Faktor yang paling berpengaruh dalam EFAS adalah keamanan data dan jaringan, karena masih belum adanya peraturan daerah dan standar operasional prosedur (SOP) mengenai pengelolaan data dan jaringan serta gangguan akses internet dan website, yang dapat mengganggu rencana dan kegiatan kota pintar serta Akses ke internet. Data penting.

Berdasarkan hasil matriks strategi SWOT IFAS dan EFAS, maka rencana strategis yang perlu dirumuskan untuk pengembangan dan implementasi smart city di Pontianak dapat mengedepankan strategi aktif yaitu memanfaatkan keunggulan untuk menangkap peluang yang ada. Dengan dukungan dan komitmen para pemimpin daerah, mereka dapat memanfaatkan aplikasi Gencil (Government Smart City and Landmark) dan aplikasi JEPIN (Integrated Pontianak Window), kemudian bekerja sama dengan pihak swasta untuk menyediakan lebih banyak tempat umum bagi masyarakat. Fasilitas internet meningkatkan partisipasi siswa. Gunakan Lembaga Penelitian dan Pengabdian Masyarakat (LPPM) untuk mensosialisasikan dan mengedukasi kota pintar Untan melakukan penelitian agar dapat mengkaji dan melaksanakan pemanfaatan teknologi yang dapat digunakan di kota pintar.Bekerja sama dengan media massa secara aktif dengan selalu menyediakan data aktual dan akurat di website agar media massa dapat meliput dan melaporkan informasi yang aktual. Bekerja sama dengan masyarakat dan UMKM dapat Kembangkan produk lokal dan berkolaborasi dengan komunitas melalui pelaporan media sosial dan pemantauan masalah publik melalui aplikasi.

Strategi pembangunan dan implementasi kota pintar oleh Pemerintah Kota Pontianak dirumuskan dengan memadukan kekuatan, kelemahan, peluang dan ancaman yang tertuang dalam hasil wawancara pemerintah, swasta, akademisi, komunitas, media massa dan masyarakat. Berdasarkan hasil wawancara, tidak semuanya digunakan. Sebaliknya, dipilih strategi yang dapat menyelesaikan permasalahan yang dihadapi oleh Pemerintah Kota Pontianak berdasarkan hasil penelitian pendahuluan yaitu data dan aplikasi yang belum terintegrasi, kapasitas sumber daya perangkat pemetaan, dan kurangnya Sosialisasi kepada masyarakat, kerjasama masih belum yang terbaik untuk merancang sistem keamanan data dan jaringan. Kemudian, hasil dari strategi ini juga akan disesuaikan dengan poin-poin kunci dari Rencana Pembangunan Jangka Menengah (RPJM) Kota Pontianak 2019-2024 dan Rencana Pembangunan Jangka Panjang Kota (RPJP) Kota Pontianak 2024-2029 yang masuk dalam Rencana Induk Kota Cerdas 2019. 
Tabel 4.1

Matriks SWOT Strategi Pengembangan dan Implementasi Smart City Pemerintah Kota Pontianak

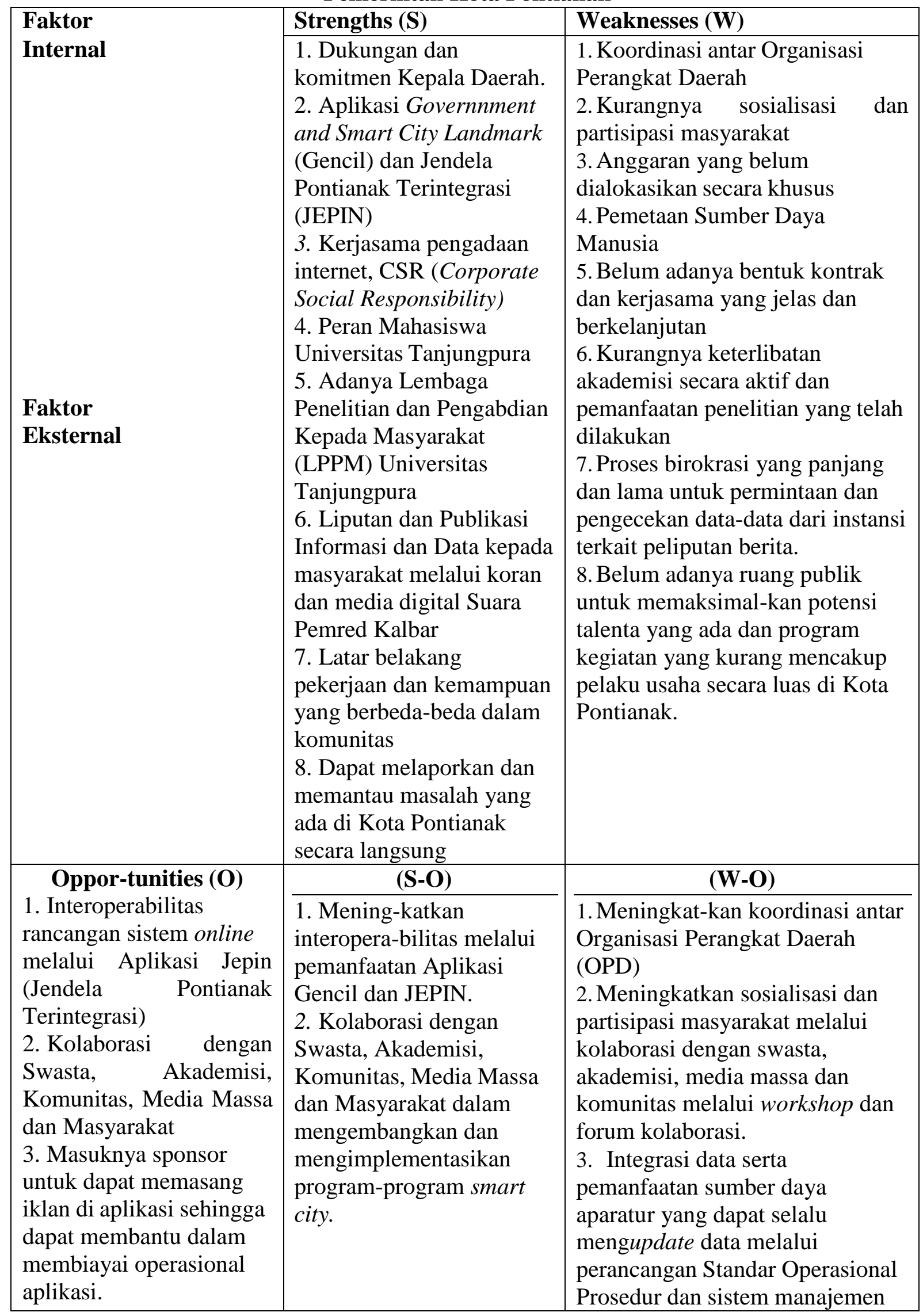




\begin{tabular}{|c|c|c|}
\hline $\begin{array}{l}\text { 4. Lul } \\
\text { inform } \\
\text { diman } \\
\text { memb } \\
\text { sosiali } \\
\text { percep } \\
\text { penger } \\
\text { city. } \\
\text { 5. Aks } \\
\text { mudah } \\
\text { secara } \\
\text { dalam } \\
6 \text {. Pen } \\
\text { produl } \\
\text { Usaha } \\
\text { Menen } \\
\text { 7. Pen } \\
\text { yang d } \\
\text { masala } \\
\text { serta n }\end{array}$ & & data. \\
\hline Threats (T) & $(\mathrm{S}-\mathrm{T})$ & $(\mathbf{W}-\mathbf{T})$ \\
\hline $\begin{array}{l}\text { 1. Keamanan data dan } \\
\text { jaringan dalam } \\
\text { pengoperasian sistem } \\
\text { informasi teknologi } \\
\text { 2. Ketersediaan server, } \\
\text { profit dan teknologi } \\
\text { penunjang. } \\
\text { 3. Kurang-nya } \\
\text { pemanfaatan riset dan } \\
\text { penelitian dan } \\
\text { keterlibatan ahli dan } \\
\text { tenaga lokal dari } \\
\text { Universitas Tanjungpura } \\
\text { Pontianak. } \\
\text { 4. Pemerintah Kota } \\
\text { Pontianak yang } \\
\text { diharapkan dapat lebih } \\
\text { transparan dan } \\
\text { mempublikasikan data- } \\
\text { data yang relevan } \\
\text { sehingga dapat diakses } \\
\text { secara online oleh publik } \\
\text { 5. Kurang sinkronnya } \\
\text { program kegiatan } \\
\text { sehingga dianggap tidak } \\
\text { dapat memberikan } \\
\text { manfaat ekonomis } \\
\text { kepada masyarakat } \\
\text { lokal/sekitar. }\end{array}$ & $\begin{array}{l}\text { 1. Berkolabo-rasi dengan } \\
\text { swasta dan akademisi } \\
\text { untuk meningkatkan } \\
\text { keamanan data dan } \\
\text { jaringan dalam } \\
\text { pengoperasian sistem } \\
\text { informasi teknologi. } \\
\text { 2. Meningkat-kan } \\
\text { ketersediaan server serta } \\
\text { sarana dan prasarana yang } \\
\text { menunjang program- } \\
\text { program smart city. } \\
\text { 3. Penyusunan program } \\
\text { yang melibatkan } \\
\text { masyarakat dan dapat } \\
\text { memberikan keuntungan } \\
\text { ekonomis kepada } \\
\text { masyarakat }\end{array}$ & $\begin{array}{l}\text { 1. Alokasi anggaran yang tidak } \\
\text { hanya untuk pemeliharaaan tetapi } \\
\text { juga untuk pengadaan dan } \\
\text { pengembangan. } \\
\text { 2. Pemetaan sumber daya manusia } \\
\text { yang dibutuhkan serta } \\
\text { peningkatan kapasitas dalam } \\
\text { pelaksanaan program smart city } \\
\text { 3. Kontrak dan kerjasama yang } \\
\text { jelas dan berkelanjutan antara } \\
\text { programmer dan Pemerintah Kota } \\
\text { Pontianak. } \\
\text { 4. Pemanfaatan riset dan } \\
\text { penelitian serta keterlibatan ahli } \\
\text { dan tenaga lokal dalam program } \\
\text { smart city. }\end{array}$ \\
\hline
\end{tabular}




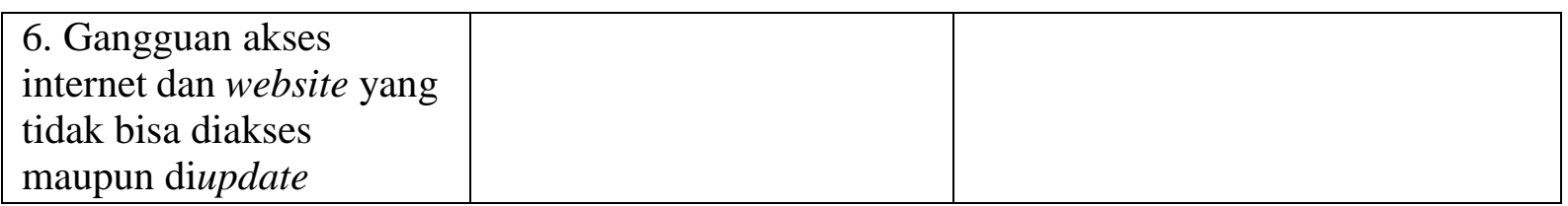

Berdasarkan matriks SWOT, maka dapat dijelaskan strategi-strategi yang dapat diadopsi untuk mengembangkan dan mengimplementasikan rencana kota pintar di Pontianak, antara lain:

a. Satu jenis. Strategi S-O (keuntungan-peluang)

Strategi S-O adalah strategi yang menggunakan semua keuntungan untuk merebut peluang. Strategi yang dapat dilakukan adalah:

1. Meningkatkan interoperabilitas melalui penggunaan aplikasi pemerintah, kota pintar dan landmark (Gencil) dan terintegrasi Pontianak Window (JEPIN). Rencana JEPIN baru yang akan disosialisasikan pada tahun 2020 juga akan dievaluasi dalam pelaksanaan pilot project GENCIL sebelumnya, sehingga rencana tersebut dapat diselesaikan dengan lebih meningkatkan koordinasi antar organisasi perangkat daerah (OPD), agar sistem dapat berjalan dengan baik.

2. Bekerja sama dengan sektor swasta, akademisi, komunitas, media massa dan publik untuk mengembangkan dan mengimplementasikan rencana kota pintar.

b. Strategi W-O (peluang kelemahan)

Strategi W-O merupakan strategi yang dikembangkan dengan meminimalkan kelemahan dengan memanfaatkan peluang yang ada. Strategi yang dapat dilakukan adalah:

1. Meningkatkan koordinasi antar organisasi perangkat daerah (OPD). Salah satunya dengan mengadakan forum dan rapat koordinasi agar dapat memprioritaskan rencana dan alokasi anggaran yang akan dilaksanakan sesuai dengan kondisi berbagai organisasi perangkat daerah (OPD).

2. Meningkatkan sosialisasi dan partisipasi masyarakat melalui kerjasama dengan pihak swasta, akademisi, media massa dan masyarakat. Misalnya dengan memanfaatkan mahasiswa dari perguruan tinggi lokal untuk mengadakan workshop dan berkolaborasi dengan pihak lain.

3. Integrasi data dan pemanfaatan sumber daya perangkat yang selalu dapat memperbarui data. Salah satu langkah yang dapat dilakukan adalah dengan menerapkan standar dalam penyajian data agar data yang ditampilkan selalu dapat diperbarui dan relevan bagi publik dan pihak yang mengaksesnya.

c. Strategi teknologi (ancaman kekuatan)

Strategi S-T merupakan strategi yang dikembangkan dengan memanfaatkan berbagai keunggulan untuk mengatasi ancaman. Strategi yang dapat dilakukan adalah:

1. Bekerja sama dengan pihak swasta dan akademisi untuk meningkatkan keamanan data dan jaringan dalam pengoperasian sistem teknologi informasi.

2. Meningkatkan ketersediaan server serta sarana dan prasarana. Diantaranya, server yang ada dapat dioptimalkan, kemudian ketersediaan sarana dan prasarana dapat dioptimalkan untuk memenuhi kebutuhan OPD terkait.

3. Mengembangkan rencana yang melibatkan masyarakat dan dapat membawa manfaat ekonomi bagi masyarakat. Rencana penggunaan teknologi terkait pemberdayaan 
masyarakat bukan hanya sekedar acara jangka panjang Jangka pendek tetapi juga jangka panjang untuk meningkatkan perekonomian masyarakat lokal.

\section{d. Strategi W-T (Weakness Threat)}

Strategi W-T merupakan strategi yang bertujuan untuk meminimalkan kelemahan dan menghindari ancaman. Strategi yang dapat dilakukan adalah:

1. Alokasi anggaran tidak hanya digunakan untuk pemeliharaan, tetapi juga untuk pengadaan dan pembangunan. OPD yang terintegrasi dengan sistem juga perlu membeli sumber daya peralatan dan sarana dan prasarana pendukung lainnya.

2. Memetakan sumber daya manusia yang dibutuhkan dan meningkatkan kemampuan untuk mengimplementasikan rencana kota pintar. Artinya, memetakan sumber daya manusia yang ada saat ini, seperti PNS nasional berlatar belakang pendidikan teknis dan peningkatan kapasitas PNS nasional melalui pelatihan yang dapat digunakan untuk menyusun rencana smart city.

3. Kontrak dan kerjasama yang jelas dan berkelanjutan antara programmer (swasta) / ahli IT dengan pemerintah kota Pontianak. Untuk dapat melakukan kerjasama yang berkelanjutan, Pemerintah Kota Pontianak dapat merancang kontrak dan merumuskan bentuk kerjasama yang jelas, dengan tujuan dan indikator yang terukur, sehingga terjalin hubungan yang baik, kemudian kontrak kerjasama sebelumnya dapat dievaluasi dan ditindaklanjuti. Agar dapat melanjutkan dan menyempurnakan prosedur yang akan dilaksanakan.

4. Memanfaatkan hasil penelitian dan melibatkan tenaga ahli dan personel lokal. Pemerintah Pontianak juga dapat memanfaatkan dan mengembangkan penelitian yang dilakukan oleh berbagai perguruan tinggi di Pontianak, dalam rangka menjalin kemitraan yang baik dan meningkatkan partisipasi yang luas. Sesuai dengan strategi di atas, dapat juga disesuaikan dengan rencana pembangunan Pontianak sendiri untuk diinternalisasikan dalam persiapan kegiatan yang dilakukan oleh masing-masing Organisasi Daerah (OPD). Alokasi anggaran dan penyesuaian persyaratan OPD yang berbeda juga akan sangat mempengaruhi prioritas rekomendasi kebijakan yang akan dilaksanakan. Namun ada enam hal yang dianggap sangat penting dalam pengembangan dan implementasi Kota Cerdas Pontianak, yaitu integrasi aplikasi, pemetaan dan peningkatan kapasitas sumber daya perangkat, infrastruktur pendukung, sosialisasi dan edukasi penggunaan teknologi informasi, Kolaborasi dengan swasta, akademisi, komunitas, media massa dan masyarakat, serta perumusan kebijakan mengenai keamanan teknologi informasi.

e. Mengembangkan kegiatan smart city Pontianak

Kegiatan perumusan dan implementasi smart city Pontianak merupakan kegiatan yang dapat dilakukan oleh stakeholders terkait pada tahap operasional untuk mendukung dan melaksanakan strategi di atas. Pernyataan ini didasarkan pada identifikasi permasalahan yang ditemukan melalui analisis analisis matriks swot pada kuadran strategi radikal, yang sejalan dengan rencana prioritas pembangunan kota pintar pada masterplan 2019, yaitu penggunaan kekuatan untuk menangkap Kun. Peluang implementasi dan pengembangan kota pintar. . Dengan demikian, Anda dapat melihat secara detail aktivitas dan indikator mana saja yang dapat digunakan sebagai tolak ukur keberhasilan strategi yang akan diterapkan: 
Karina Oktriastra

1. Interoperabilitas, yaitu melalui penggunaan maksimal aplikasi JEPIN (Integrated Pontianak Window) dan Gencil (Government Smart City and Landmark).

\begin{tabular}{|l|l|}
\hline $\begin{array}{l}\text { Kegiatan yang } \\
\text { dapat dilakukan }\end{array}$ & \\
\hline $\begin{array}{l}\text { 1. Sosialisasi } \\
\text { Aplikasi JEPIN } \\
\text { kepada Aparatur } \\
\begin{array}{l}\text { Sipil Negara dan } \\
\text { Masyarakat }\end{array}\end{array}$ & $\begin{array}{l}\text { 1. Peningkatan jumlah ASN dan Masyarakat yang mengunduh dan } \\
\text { memanfaatkan aplikasi JEPIN }\end{array}$ \\
\hline $\begin{array}{l}\text { 2. Merancang } \\
\text { sistem aplikasi }\end{array}$ & $\begin{array}{l}\text { 1. Peningkatan jumlah pengguna dan masyarakat yang memanfaatkan } \\
\text { aplikasi. }\end{array}$ \\
$\begin{array}{l}\text { friendly, aplikasi } \\
\text { yang terintegrasi } \\
\text { lintas OPD. }\end{array}$ & \\
\hline $\begin{array}{l}\text { 3. } \\
\text { Mengalokasikan } \\
\text { dan memberikan } \\
\text { pelatihan dan } \\
\text { bimbingan teknis } \\
\text { kepada ASN yang } \\
\text { akan ditunjuk } \\
\text { sebagai admin. }\end{array}$ & $\begin{array}{l}\text { 1. Prosentase layanan pengaduan secara online yang ditindaklanjuti } \\
\text { secara tepat waktu }\end{array}$ \\
\hline $\begin{array}{l}\text { 4. Menjadwalkan } \\
\text { rapat untuk } \\
\text { organisasi } \\
\text { perangkat daerah } \\
\text { (OPD) maupun diinput ke dalam sistem } \text { online dengan tepat waktu dan } \\
\text { asistensi untuk } \\
\text { dapat } \\
\text { mengintegrasi } \\
\text { inovasi aplikasi ke } \\
\text { dalam sistem } \\
\text { aplikasi JEPIN. }\end{array}$ & $\begin{array}{l}\text { 1. Aplikasi JEPIN yang terintegrasi dan terpadu dengan layanan di } \\
\text { seluruh OPD di Kota Pontianak. }\end{array}$ \\
\end{tabular}

2. Melakukan kolaborasi dengan pihak swasta, akademisi, komunitas, media massa dan masyarakat untuk pengembangan program smart city.

\begin{tabular}{|l|l|}
\hline $\begin{array}{l}\text { Kegiatan yang dapat } \\
\text { dilakukan }\end{array}$ & \multicolumn{1}{|c|}{ Indikator Keberhasilan } \\
\hline $\begin{array}{l}\text { 1.Kolaborasi dengan swasta : } \\
\text { - Pemanfaatan Corporate } \\
\text { Social Responsibility (CSR) } \\
\text { untuk memberikan dukungan } \\
\text { dalam kegiatan penelitian } \\
\text { dan pengembangan maupun } \\
\text { penggunaan hasil riset dari } \\
\text { akademisi. }\end{array}$ & \\
\hline $\begin{array}{l}\text { 2. Kolaborasi dengan } \\
\text { akademisi: }\end{array}$ & \\
\hline
\end{tabular}




\begin{tabular}{|c|c|}
\hline $\begin{array}{l}\text { - Inovasi di bidang teknologi } \\
\text { dengan memanfaatkan } \\
\text { penelitian di bidang } \\
\text { teknologi informasi dari } \\
\text { universitas } \\
\text { - Memberikan bantuan dana } \\
\text { riset untuk mendorong hasil } \\
\text { penelitian dalam bidang } \\
\text { teknologi informasi yang } \\
\text { dapat dimanfaatkan dalam } \\
\text { program smart city } \\
\text { - Peningkatan peran } \\
\text { mahasiswa dalam kegiatan } \\
\text { kampus untuk dapat } \\
\text { memperkenalkan dan } \\
\text { melakukan edukasi terhadap } \\
\text { masyarakat dalam } \\
\text { pemanfaatan IT dan } \\
\text { pelaksanaan program smart } \\
\text { city }\end{array}$ & $\begin{array}{l}\text { city di Kota Pontianak. } \\
\text { 2. Terwujudnya keterlibatan mahasiswa dalam } \\
\text { peningkatan sosialisasi dan edukasi kepada masyarakat } \\
\text { terkait pemanfaatan teknologi. }\end{array}$ \\
\hline $\begin{array}{l}\text { 3. Kolaborasi dengan } \\
\text { komunitas : } \\
\text { - Penyediaan fasilitas tempat } \\
\text { untuk pelaksanaan pameran, } \\
\text { workshop, kegiatan-kegiatan } \\
\text { komunitas lokal. } \\
\text { - Publikasi kegiatan-kegiatan } \\
\text { komunitas dalam aplikasi } \\
\text { JEPIN. }\end{array}$ & $\begin{array}{l}\text { 1. Terlaksananya kegiatan-kegiatan dari komunitas yang } \\
\text { berkolaborasi dengan pemerintah dan memanfaatkan } \\
\text { teknologi informasi. }\end{array}$ \\
\hline $\begin{array}{l}\text { 4. Kolaborasi dengan media } \\
\text { massa : } \\
\text { - Melakukan kolaborasi } \\
\text { dalam liputan, ulasan dan } \\
\text { publikasi dalam pemberitaan } \\
\text { program-program smart city } \\
\text { yang dilaksanakan. }\end{array}$ & $\begin{array}{l}\text { 1. Munculnya public awareness dan meningkatnya } \\
\text { partisipasi masyarakat dari pemberitaan-pemberitaan yang } \\
\text { dilakukan dari media massa terkait program-program smart } \\
\text { city. }\end{array}$ \\
\hline $\begin{array}{l}\text { 5. Kolaborasi dengan } \\
\text { masyarakat : } \\
\text { - Menyediakan fasilitas } \\
\text { publik dalam bentuk } \\
\text { komputer, laptop, koneksi } \\
\text { internet maupun helpdesk } \\
\text { untuk mengakses pelayanan } \\
\text { publik berbasis internet. } \\
\text { - Pengadaan wifi di fasilitas } \\
\text { umum yang ada di Kota } \\
\text { Pontianak }\end{array}$ & $\begin{array}{l}\text { 1. Meningkatnya partisipasi masyarakat dalam program- } \\
\text { program smart city. }\end{array}$ \\
\hline
\end{tabular}

3. Melakukan koordinasi terus menerus antar Organisasi Perangkat Daerah (OPD) pelaksana program smart city 


\begin{tabular}{|l|l|}
\hline $\begin{array}{l}\text { Kegiatan yang dapat } \\
\text { dilakukan }\end{array}$ & Indikator Keberhasilan \\
\hline $\begin{array}{l}\text { 1. Rapat koodinasi secara } \\
\text { berkala antara Tim Teknis } \\
\text { Smart City dan Organisasi } \\
\text { Perangkat Daerah (OPD) } \\
\text { dalam pelaksanaan program- } \\
\text { program smart city. }\end{array}$ & $\begin{array}{l}\text { 1. Pelaksanaan program-program terkait smart city di } \\
\text { semua OPD. }\end{array}$ \\
\hline $\begin{array}{l}\text { 2. Menyelaraskan program- } \\
\text { program smart city dengan } \\
\text { indikator kinerja organisasi } \\
\text { perangkat daerah (OPD) }\end{array}$ & OPD \\
\hline
\end{tabular}

4. Melaksanakan kegiatan sosialisasi untuk meningkatkan partisipasi masyarakat dalam pengembangan program smart city.

\begin{tabular}{|l|l|}
\hline $\begin{array}{l}\text { Kegiatan yang dapat } \\
\text { dilakukan }\end{array}$ & Indikator Keberhasilan \\
\hline $\begin{array}{l}\text { 1. Workshop maupun forum } \\
\text { diskusi terbuka mengenai } \\
\text { pemanfaatan teknologi } \\
\text { informasi di Kota Pontianak. }\end{array}$ & $\begin{array}{l}\text { 1. Terselenggaranya sosialisasi yang dapat memacu } \\
\text { peningkatan partisipasi dalam pelaksanaan program- } \\
\text { program smart city. }\end{array}$ \\
\hline
\end{tabular}

5. Integrasi data serta pemanfaatan sumber daya aparatur yang dapat selalu mengupdate data.

\begin{tabular}{|l|l|}
\hline $\begin{array}{l}\text { Kegiatan yang dapat } \\
\text { dilakukan }\end{array}$ & Indikator Keberhasilan \\
\hline Perancangan Standar & Penyelenggaraan kegiatan yang memanfaatkan teknologi \\
Operasional Prosedur (SOP) & informasi yang sesuai dengan prosedur standar untuk \\
dalam mempublikasikan data & meningkatkan kualitas pelayanan publik. \\
dan informasi yang dapat & \\
diakses publik secara online \\
melalui aplikasi
\end{tabular}

6. Melakukan kolaborasi dengan swasta dan akademisi untuk meningkatkan keamanan data dan jaringan.

\begin{tabular}{|c|c|}
\hline $\begin{array}{l}\text { Kegiatan yang dapat } \\
\text { dilakukan }\end{array}$ & Indikator Keberhasilan \\
\hline $\begin{array}{l}\text { Perancangan peraturan } \\
\text { mengenai Sistem Manajemen } \\
\text { Keamanan Data dan Jaringan } \\
\text { di Kota Pontianak dengan } \\
\text { berkonsultasi dengan pihak } \\
\text { swasta dan akademisi yang } \\
\text { memiliki basis IT terkait } \\
\text { sistem manajemen keamanan } \\
\text { data dan jaringan. }\end{array}$ & $\begin{array}{l}\text { Adanya peraturan mengenai sistem manajemen keamanan } \\
\text { data dan jaringan sehingga memiliki standar operasional } \\
\text { agar dapat menjaga kerahasiaan, integritas dan ketersediaan } \\
\text { informasi. }\end{array}$ \\
\hline
\end{tabular}


7. Meningkatkan ketersediaan server serta sarana dan prasarana.

\begin{tabular}{|c|c|}
\hline $\begin{array}{llr}\begin{array}{l}\text { Kegiatan } \\
\text { dilakukan }\end{array} & \text { yang } \quad \text { dapat } \\
\end{array}$ & Indikator Keberhasilan \\
\hline 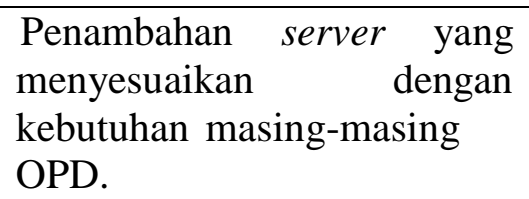 & Server yang sesuai dengan kebutuhan OPD \\
\hline $\begin{array}{l}\text { Penganggaran pengadaan dan } \\
\text { pemeliharaan } \\
\text { komputer/laptop yang } \\
\text { bekerja dengan optimal serta } \\
\text { koneksi internet yang cepat. }\end{array}$ & $\begin{array}{c}\text { Komputer/ laptop yang dapat dimanfaatkan untuk } \\
\text { pelaksanaan kegiatan sesuai dengan kebutuhan operasional. }\end{array}$ \\
\hline
\end{tabular}

8. Penyusunan program yang melibatkan masyarakat serta memberikan keuntungan ekonomis kepada masyarakat.

\begin{tabular}{|c|c|}
\hline $\begin{array}{l}\text { Kegiatan yang dapat } \\
\text { dilakukan }\end{array}$ & Indikator Keberhasilan \\
\hline $\begin{array}{l}\text { Pelatihan kepada } \\
\text { masyarakat melalui } \\
\text { pembuatan produk yang } \\
\text { menjadi ciri khas daerah } \\
\text { seperti pengolahan } \\
\text { produk lidah buaya } \\
\text { dengan memanfaatkan } \\
\text { aplikasi seperti dengan } \\
\text { video tutorial learning. }\end{array}$ & $\begin{array}{l}\text { Kemampuan masyarakat dalam mengolah dan memproduksi } \\
\text { produk lokal. }\end{array}$ \\
\hline $\begin{array}{l}\text { Publikasi berbagai festival } \\
\text { daerah yang unik } \\
\text { dipadukan } \\
\text { penjualan online } \\
\text { daerah meduk } \\
\text { JEPIN. } \\
\end{array}$ & $\begin{array}{l}\text { 1. Penjualan produk lokal } \\
\text { Peningkatan ekonomi masyarakat }\end{array}$ \\
\hline
\end{tabular}

9. Alokasi anggaran yang tidak hanya untuk pemeliharaaan tetapi juga untuk pengadaan dan pengembangan.

\begin{tabular}{|l|l|}
\hline $\begin{array}{l}\text { Kegiatan yang dapat } \\
\text { dilakukan }\end{array}$ & Indikator Keberhasilan \\
\hline $\begin{array}{l}\text { Pengalokasian anggaran } \\
\text { terkait program smart } \\
\text { city dari semua OPD } \\
\text { yang terlibat. }\end{array}$ & Terimplementasinya program-program smart city \\
\hline
\end{tabular}

10.Pemetaan sumber daya manusia yang dibutuhkan serta peningkatan kapasitas dalam pelaksanaan program smart city.

\begin{tabular}{|l|l|l|l|}
\hline $\begin{array}{l}\text { Kegiatan yang dapat } \\
\text { dilakukan }\end{array}$ & Indikator Keberhasilan & & \\
\hline $\begin{array}{c}\text { Melakukan talent } \\
\text { scouting dan talent }\end{array}$ & $\begin{array}{l}\text { Adanya admin yang bertugas mengoperasionalkan } \\
\text { melaksanakan program-program smart city di tiap OPD. }\end{array}$ & dan \\
\hline
\end{tabular}




\begin{tabular}{|l|l|}
\hline pool melalui e-karir & \\
untuk menempatkan & \\
ASN yang memiliki & \\
kapasitas untuk & \\
melaksanakan & \\
program-program & \\
smart city di masing- & \\
masing OPD & \\
\hline Melakukan pendidikan & ASN yang mampu mengimplementasikan program-program smart \\
dan pelatihan berbasis & city di setiap OPD. \\
IT kepada ASN. & \\
\hline
\end{tabular}

11.Kontrak dan kerjasama yang jelas dan berkelanjutan antara programmer/ahli IT (swasta) dan Pemerintah Kota Pontianak.

\begin{tabular}{|c|c|}
\hline Kegiatan yang dapat dilakukan & Indikator Keberhasilan \\
\hline $\begin{array}{l}\text { Penyusunan Perjanjian } \\
\text { Kerjasama, Nota Kesepahaman } \\
\text { (MoU) maupun kontrak } \\
\text { kerjasama } \\
\text { programmer/swasta/komunitas/ } \\
\text { pihak lainnya dalam setiap } \\
\text { kegiatan yang akan dilakukan, } \\
\text { dengan bahasa } \\
\text { perjanjian/kontrak yang jelas, } \\
\text { tidak multitafsir, memiliki } \\
\text { tujuan bersama yang ingin } \\
\text { dicapai, memuat jangka dan } \\
\text { batas waktu yang diharapkan, } \\
\text { serta melakukan evaluasi dan } \\
\text { tindak lanjut mengenai } \\
\text { keberlangsungan kerjasama. }\end{array}$ & $\begin{array}{l}\text { Terciptanya kerjasama/kolaborasi yang memenuhi tujuan } \\
\text { yang bersinergi antara Pemerintah Kota Pontianak dan } \\
\text { pihak lainnya. }\end{array}$ \\
\hline
\end{tabular}

12. Pemanfaatan riset dan penelitian serta keterlibatan ahli dan tenaga lokal.

\begin{tabular}{|l|l|}
\hline Kegiatan yang dapat dilakukan & Indikator Keberhasilan \\
\hline $\begin{array}{l}\text { Pemanfaatan hasil penelitian dari Lembaga } \\
\begin{array}{l}\text { Penelitian Universitas, dapat dalam } \\
\text { bentuk menerima proposal inovasi dari } \\
\text { ahli dan tenaga lokal. }\end{array}\end{array}$ & $\begin{array}{c}\text { Adanya hasil penelitian yang dapat menjadi } \\
\text { inovasi dalam program smart city }\end{array}$ \\
\hline $\begin{array}{l}\text { Keterlibatan ahli dan tenaga lokal dalam } \\
\text { pelaksanaan program-program smart city }\end{array}$ & $\begin{array}{l}\text { Kolaborasi dalam implementasi program smart } \\
\text { city. }\end{array}$ \\
\hline
\end{tabular}

Tentunya, dua belas strategi yang dapat diterapkan juga dapat diterapkan dengan menyesuaikan enam dimensi smart city (yaitu smart governance, smart brand, smart economy, smart life, smart society, smart environment). Hal ini juga dapat disesuaikan dengan roadmap pembangunan kota pintar jangka menengah Pontianak (2019: 25) yaitu melalui tahap pertama (2019-2020) fokus pada pengembangan sumber daya manusia dan pengawasan kebijakan, dan tahap kedua (2021-2022) berfokus pada Pengembangan infrastruktur / perangkat lunak / aplikasi, tahap ketiga (2023) integrasi / interkoneksi, dan tahap keempat 
(2024) adalah pengembangan berkelanjutan. Alternatif strategi yang dapat melaksanakan kegiatan-kegiatan di atas diharapkan dapat menjadi masukan untuk menyelesaikan permasalahan implementasi dan pengembangan smart city Pontianak, sehingga dapat mempercepat pelaksanaan kegiatan yang dapat lebih terintegrasi dengan kapasitas peningkatan sumber daya perangkat, dan selanjutnya pada stakeholders. Kolaborasi antara mereka untuk meningkatkan partisipasi masyarakat dan lebih meningkatkan sistem informasi keamanan data dan keamanan jaringan Kota Pintar Pontianak.

Selain itu, berdasarkan hasil analisis SWOT tersebut di atas, dapat pula digunakan rencana aksi untuk merancang, yang dapat digunakan untuk melihat kegiatan apa saja yang dapat dilakukan dalam pengembangan dan implementasi rencana kota pintar di Pontianak:

Rencana aksi: Sinkronisasi integrasi dan pengembangan aplikasi melalui kinerja OPD dan kolaborasi dalam Rencana Kota Cerdas

Manfaat / hasil action plan: rencana kerja / kegiatan, RKA-DPA dengan file RKPD dan RPJMD dengan masterplan kota pintar dan indikator kinerja usulan rencana / kegiatan kota pintar yang tercantum dalam rencana kerja, RKA-DPA Sinkronisasi dengan tujuan kinerja dapat terukur secara jelas sehingga dapat bekerjasama dengan pihak swasta, akademisi, komunitas, media massa, dan masyarakat untuk mengembangkan dan mengimplementasikan rencana smart city, sehingga mempercepat perwujudan visi dan misi smart city Pontianak.

Dalam meningkatkan tata kelola pemerintahan yang baik (good governance) dan menggunakan teknologi dalam mewujudkan konsep kota pintar, rencana kerja dan RKA-DPA juga harus sesuai dengan target kinerja pemerintah daerah dalam RKPD, RPJMD dan rencana induk kota pintar. Kemudian, penentuan indikator OPD dan indikator kinerja harus dapat diukur dan konsisten dengan indikator dan indikator kinerja pemerintah daerah. Setelah pendampingan dan sinkronisasi RKA-DPA dengan rencana kerja OPD, RPJMD, dan RKPD APBD tahun anggaran 2020, saya berharap berkas RKA-DPA dapat memenuhi rencana pembangunan, selain itu juga dapat memuat konsep kota pintar yang ingin dikembangkan. Sehingga Anda dapat mewujudkan visi dan misi kota pintar yang ingin Anda wujudkan di Pontianak.

Berdasarkan roadmap pengembangan Kota Pintar Pontianak, implementasi dan pengembangan Kota Cerdas Pontianak dapat dipetakan sesuai dengan pengembangan roadmap tahap pertama (2019-2020) yaitu fokus pada pengembangan sumber daya manusia dan kebijakan serta regulasi. , Bisa dilakukan melalui pengembangan dan pemberdayaan. Kelompok masyarakat, penggambaran kemampuan PNS, bimbingan teknis dan pelatihan berbasis teknologi informasi. Fokus pada pengembangan infrastruktur / perangkat lunak / aplikasi dapat dilaksanakan dengan mengembangkan sistem informasi berbasis TIK di semua organisasi perangkat daerah, dan mengelola layanan publik online di semua departemen, meningkatkan sarana dan prasarana, serta membangun fasilitas layanan publik online terintegrasi fase kedua (2021-2022). Dapat diintegrasikan / saling berhubungan dengan mengintegrasikan berbagai aplikasi ke dalam satu aplikasi, mengintegrasikan data kependudukan ke dalam sistem / aplikasi pelayanan publik, dan mengintegrasikan informasi data daerah ke dalam platform online yang terintegrasi. fase (2023). Tahap keempat (2024) adalah pengembangan lebih lanjut, yaitu dapat mengumpulkan dan mengolah informasi publik di lingkungan pemerintah daerah, menyusun database, secara aktif memberikan izin 
pelayanan, kemudian memantau dan mengevaluasi sistem informasi berbasis teknologi yang diterapkan dan mengoptimalkan kegiatan yang telah dilakukan.

Untuk keempat tahapan roadmap perencanaan keseluruhan di atas, kegiatan yang dapat dilakukan sesuai dengan hasil analisis teori Lev-On dan strategi agresif matriks SWOT, sebagai berikut:

\section{Tabel 5.2}

Peta Jalan Tahapan Kegiatan Smart City Pontianak

\begin{tabular}{|c|c|c|}
\hline Kegiatan & $\begin{array}{l}\text { Pihak yang } \\
\text { Terlibat }\end{array}$ & Output \\
\hline \multicolumn{3}{|c|}{$\begin{array}{c}\text { Tahap } 1 \text { (2019-2020) Pengembangan SDM } \\
\text { dan Regulasi Kebijakan }\end{array}$} \\
\hline $\begin{array}{l}\text { Pelatihan berbasis TIK bagi } \\
\text { seluruh PNS di lingkungan } \\
\text { Pemkot Pontianak }\end{array}$ & $\begin{array}{l}\text { Diskominfo, } \\
\text { Akademisi, } \\
\text { Swasta }\end{array}$ & $\begin{array}{l}\text { Jumlah PNS memenuhi } \\
\text { standar kompetensi teknis } \\
\text { Sistem Pelayanan Berbasis } \\
\text { Elektronik (Index SPBE) }\end{array}$ \\
\hline $\begin{array}{l}\text { Pemberdaya-an kelompok } \\
\text { masyarakat dalam memanfaat- } \\
\text { kan teknologi }\end{array}$ & $\begin{array}{l}\text { Dinas Sosial, } \\
\text { Diskominfo, } \\
\text { Komunitas, } \\
\text { Akademisi, } \\
\text { Media Massa }\end{array}$ & $\begin{array}{l}\text { Meningkatnya jumlah } \\
\text { masyarakat yang } \\
\text { memanfaatkan aplikasi JEPIN }\end{array}$ \\
\hline $\begin{array}{l}\text { Edukasi kepada seluruh lapisan } \\
\text { masyarakat tentang penggunaaan } \\
\text { teknologi informasi khususnya } \\
\text { dalam mengakses pelayanan } \\
\text { publik }\end{array}$ & $\begin{array}{l}\text { Dinas Sosial, } \\
\text { Akademisi, } \\
\text { Komunitas, } \\
\text { Media Massa, } \\
\text { Swasta. }\end{array}$ & $\begin{array}{l}\text { Prosentase masyarakat yang } \\
\text { menggunakan aplikasi JEPIN }\end{array}$ \\
\hline $\begin{array}{l}\text { Peraturan mengenai } \\
\text { Sistem Manajemen Keamanan } \\
\text { Data dan Jaringan }\end{array}$ & $\begin{array}{l}\text { Diskominfo, } \\
\text { Akademisi, } \\
\text { Programmer/ } \\
\text { Ahli IT }\end{array}$ & Peraturan Daerah \\
\hline \multicolumn{3}{|c|}{ Tahap 2 (2021-2022) : Pengembangan Infrastruktur/Software/Aplikasi } \\
\hline $\begin{array}{l}\text { Meningkatkan ketersediaan } \\
\text { server serta sarana prasarana } \\
\text { yang menunjang program- } \\
\text { program smart city }\end{array}$ & $\begin{array}{l}\text { Bappeda, } \\
\text { Diskominfo, } \\
\text { Badan Keuangan } \\
\text { Daerah, Swasta, } \\
\text { Ahli IT }\end{array}$ & $\begin{array}{l}\text { Server, sarana dan prasarana } \\
\text { yang menunjang di tiap OPD }\end{array}$ \\
\hline $\begin{array}{l}\text { Pengemba-ngan fintech dengan } \\
\text { bank daerah (kartu untuk segala } \\
\text { transaksi) }\end{array}$ & $\begin{array}{l}\text { Badan Keuangan } \\
\text { dan Aset Daerah, } \\
\text { Swasta }\end{array}$ & $\begin{array}{l}\text { Penggunaan kartu untuk } \\
\text { segala transaksi }\end{array}$ \\
\hline $\begin{array}{l}\text { Pengem-bangan infrastruktur dan } \\
\text { fasilitas umum yang menunjang } \\
\text { sistem pelayanan online. }\end{array}$ & $\begin{array}{l}\text { Dinas Pekerjaan } \\
\text { Umum, Swasta }\end{array}$ & $\begin{array}{l}\text { Infrastruktur dan fasilitas } \\
\text { publik untuk mengakses } \\
\text { pelayanan online }\end{array}$ \\
\hline $\begin{array}{l}\text { Integrasi dan publikasi berbagai } \\
\text { destinasi wisata dan festival } \\
\text { daerah }\end{array}$ & $\begin{array}{l}\text { Dinas Pemuda, } \\
\text { Olahraga } \\
\text { dan Pariwisata, } \\
\text { Media Massa, } \\
\text { Swasta. } \\
\end{array}$ & $\begin{array}{l}\text { Meningkatnya jumlah } \\
\text { wisatawan yang mendapatkan } \\
\text { informasi dari aplikasi }\end{array}$ \\
\hline \multicolumn{3}{|c|}{ Tahap 3 (2023) Integrasi/Interkoneksi } \\
\hline $\begin{array}{l}\text { Integrasi berbagai aplikasi dan } \\
\text { sistem informasi menjadi single }\end{array}$ & $\begin{array}{l}\text { Dinas } \\
\text { Komunikasi dan }\end{array}$ & $\begin{array}{l}\text { Aplikasi dan sistem informasi } \\
\text { terpadu }\end{array}$ \\
\hline
\end{tabular}




\begin{tabular}{|c|c|c|}
\hline aplikasi. & $\begin{array}{l}\text { Informatika, } \\
\text { Swasta, } \\
\text { Ahli IT/ } \\
\text { Programmer }\end{array}$ & \\
\hline $\begin{array}{l}\text { Integrasi dan pengelolaan sistem } \\
\text { pelayanan publik secara terpusat. }\end{array}$ & $\begin{array}{l}\text { Dinas } \\
\text { Komunikasi dan } \\
\text { Informatika, } \\
\text { Swasta, Ahli IT/ } \\
\text { Programmer }\end{array}$ & $\begin{array}{l}\text { Portal Pelayanan Publik } \\
\text { Terintegrasi }\end{array}$ \\
\hline $\begin{array}{l}\text { Kolaborasi publikasi pemberitaan } \\
\text { dengan media cetak dan media } \\
\text { elektronik }\end{array}$ & $\begin{array}{l}\text { Bid. Humas } \\
\text { Setda, } \\
\text { Media Massa }\end{array}$ & $\begin{array}{l}\text { Publikasi dan Pemberitaan di } \\
\text { media cetak dan media } \\
\text { elektronik }\end{array}$ \\
\hline
\end{tabular}

\begin{tabular}{|c|c|c|}
\hline \multicolumn{3}{|l|}{ Tahap 4 (2024) Pengembangan Lanjutan } \\
\hline $\begin{array}{l}\text { Pengumpulan dan pengolahan informasi } \\
\text { publik dalam database Kota Pontianak }\end{array}$ & $\begin{array}{l}\text { Dinas } \\
\text { Komunikasi } \\
\text { dan } \\
\text { Informatika, } \\
\text { Swasta }\end{array}$ & $\begin{array}{l}\text { Pusat Data Base Kota } \\
\text { Pontianak }\end{array}$ \\
\hline $\begin{array}{l}\text { Monitoring dan evaluasi terhadap } \\
\text { mekanisme dan prosedur penyelenggaraan } \\
\text { sistem informasi dan pelayanan publik } \\
\text { online. }\end{array}$ & $\begin{array}{l}\text { Dinas } \\
\text { Komunikasi } \\
\text { dan } \\
\text { Informatika, } \\
\text { Swasta, } \\
\text { Akademisi, } \\
\text { Komunitas, } \\
\text { Media } \\
\text { Massa }\end{array}$ & $\begin{array}{l}\text { Mekanisme dan Prosedur } \\
\text { Penyelenggaraan Sistem } \\
\text { Informasi dan Pelayanan } \\
\text { Publik Online }\end{array}$ \\
\hline
\end{tabular}

Berdasarkan tabel di atas, terlihat beberapa tahapan implementasi dan pengembangan yang dapat dilakukan dalam konteks pemanfaatan teknologi dan penguatan kerjasama dengan pihak swasta, akademisi, media massa, komunitas, dan masyarakat. Hal ini diharapkan dapat mempercepat penerapan dan pengembangan teknologi dan informasi yang bertujuan untuk menyelesaikan permasalahan masyarakat, serta meningkatkan efektifitas dan efisiensi penyelenggaraan pemerintahan di Pontianak serta perwujudan visi dan misi.

\section{Kesimpulan}

Berdasarkan hasil kajian yang telah dilakukan, maka kesimpulan yang dapat diambil sebagai strategi Pemerintah Kota Pontianak dalam mengembangkan dan mengimplementasikan kota pintar antara lain: 1) Rencana induk kota pintar yang disusun Pontianak tahun 2019 meliputi enam aspek yang masih dibutuhkan. JEPIN diformulasikan secara khusus melalui aplikasi, sehingga dapat diintegrasikan dengan berbagai sistem pelayanan publik dari berbagai organisasi perangkat daerah (OPD). 2) Berdasarkan hasil analisis SWOT yang telah dilakukan maka akan menggunakan strategi proaktif yaitu melalui kerjasama dengan pihak lain seperti swasta, akademisi, komunitas, media massa, dan masyarakat dengan menggunakan kekuatannya untuk merebut peluang yang ada. 3) Pengembangan dan implementasi strategi smart city dapat dilakukan melalui interoperabilitas, yaitu dengan menggunakan aplikasi dan website JEPIN, pemetaan 


\section{Karina Oktriastra}

peningkatan berbasis IT dan pelatihan pencarian bakat dan talent pool, serta alokasi anggaran untuk setiap OPD yang akan dibeli dan teknologi Gunakan infrastruktur dan peralatan yang relevan untuk bekerja sama dengan sektor swasta, akademisi, media massa, komunitas, dan publik untuk memanfaatkan bakat lokal, menggunakan penelitian untuk mengembangkan rencana kota pintar, dan merancang rencana keselamatan.

Adapun saran yang dikemukakan dalam pengembangan dan implementasi kota pintar Pemprov Pontianak adalah:

1) Selama integrasi aplikasi dan interoperabilitas, Anda dapat menggunakan aplikasi JEPIN (jendela Pontianak terintegrasi) sehingga Anda dapat mengakses semua program inovatif yang dikembangkan oleh setiap organisasi instrumen regional (OPD). Kemudian, petakan sumber daya peralatan yang diperlukan untuk menjalankan program ini. Serta mengimbangi indikator kinerja OPD yang relevan sehingga teknologi informasi dapat dikembangkan sesuai dengan kemampuan dan tanggung jawab utama masing-masing OPD. 2) Bekerjasama dengan pihak swasta, komunitas, akademisi, media massa dan masyarakat dalam bentuk kerjasama yang jelas sehingga dapat diukur dan dievaluasi dengan baik, seperti menggunakan CSR (Corporate Social Responsibility) untuk meningkatkan partisipasi mahasiswa melalui kegiatan pengabdian kepada masyarakat. Peran Sosialisasi Penggunaan aplikasi, penggunaan hasil penelitian, publikasi kegiatan masyarakat dalam aplikasi, kolaborasi media massa yang meliput kegiatan smart city, dan ketersediaan fasilitas umum agar masyarakat lebih mudah mengakses layanan publik online. 3) Merancang prosedur operasi standar (SOP) terkait keamanan data dan jaringan dengan pihak swasta (programmer) dan akademisi untuk melindungi proses operasi program kota pintar agar dapat berjalan dengan lancar dan melalui langkah-langkah yang sesuai. 


\section{Bibliografi}

Bower, J. L., \& Christensen, C. M. (1995). Disruptive technologies: catching the wave.

BPS Kota Pontianak. (2019). Statistik Kesejahteraan Rakyat Kota Pontianak 2019. CV. Grahafika Utama Press.

Caragliu, A., Del Bo, C., \& Nijkamp, P. (2009). Smart cities in Europe [C/OL]. Proceedings of the 3rd Central European Conference in Regional Science-CERS.

Greco, I., \& Bencardino, M. (2014). The paradigm of the modern city: SMART and SENSEable Cities for smart, inclusive and sustainable growth. International Conference on Computational Science and Its Applications, 579-597.

Insani, P. A. (2017). Mewujudkan Kota Responsif Melalui Smart City. PUBLISIA: Jurnal Ilmu Administrasi Publik, 2(1), 25-31.

Lom, M., Pribyl, O., \& Svitek, M. (2016). Industry 4.0 as a part of smart cities. 2016 Smart Cities Symposium Prague (SCSP), 1-6.

Miriam, P., \& Lev-On, P. (2013). What Makes a „Smart City.“ SNI Energy Forum.

Mursalim, S. W. (2017). Implementasi kebijakan smart city di Kota Bandung. Jurnal Ilmu Administrasi, 14(1), 126-138.

Raco, J. R. (2010). Metode penelitian kualitatif. Gramedia Widiasarana Indonesia.

Tim Teknis Pontianak Smart City. (2019a). Buku 1 Analisis Strategis: Master Plan Pontianak Smart City Tahun 2019-2029.

Tim Teknis Pontianak Smart City. (2019b). Buku 2 Master Plan Pontianak Smart City Tahun 2019-2029.

Tim Teknis Pontianak Smart City. (2019c). Buku 3 Executive Summary Masterplan Pontianak Smart City Tahun 2019-2029. 